
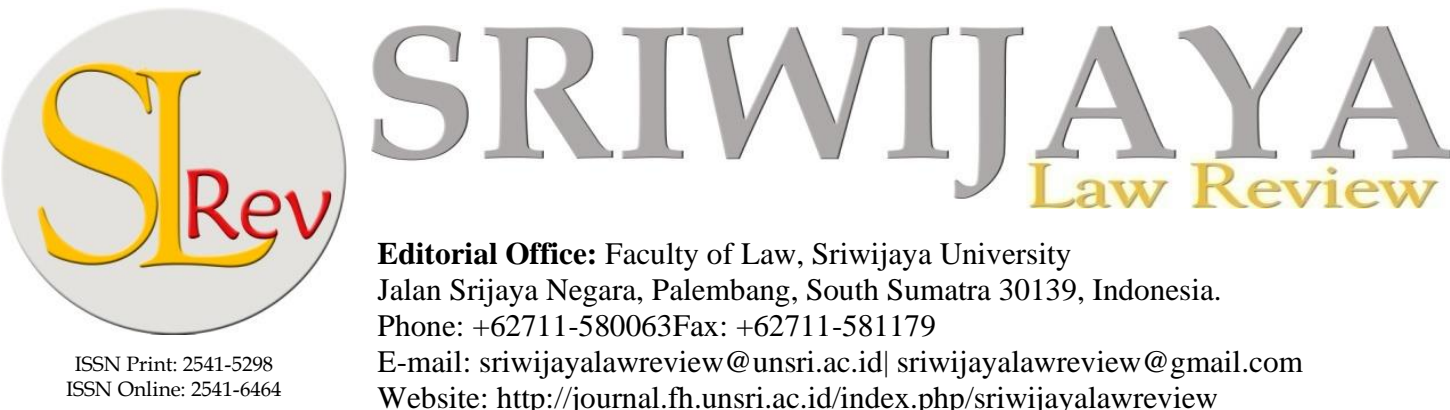

Editorial Office: Faculty of Law, Sriwijaya University

Jalan Srijaya Negara, Palembang, South Sumatra 30139, Indonesia.

Phone: +62711-580063Fax: +62711-581179

E-mail: sriwijayalawreview@unsri.ac.id| sriwijayalawreview@gmail.com

Website: http://journal.fh.unsri.ac.id/index.php/sriwijayalawreview

\title{
The Rationalization of Debt Discharge Policy for Individual Debtors in Indonesian Bankruptcy Regime
}

\author{
Robert, ${ }^{\mathrm{a}^{*}}$ Rosa Agustina, ${ }^{\mathrm{a}}$ and Bismar Nasution ${ }^{\mathrm{b}}$ \\ $a^{*}$ Faculty of Law, Universitas Indonesia, Indonesia. Corresponding author Robert, email: rob- \\ sulai12@gmail.com \\ b Faculty of Law, Universitas Sumatera Utara, Indonesia. Email: bismarnasution@gmail.com
}

\begin{tabular}{|c|c|}
\hline Article & Abstract \\
\hline $\begin{array}{l}\begin{array}{l}\text { Keywords: } \\
\text { Bankruptcy; Debt dis- } \\
\text { charge; Individual } \\
\text { Debtors; Indonesia. }\end{array} \\
\text { Article History } \\
\text { Received: Des 2, 2020; } \\
\text { Reviewed: Jan 20, 2022; } \\
\text { Accepted: Jan 30, 2022; } \\
\text { Published: Jan 31, 2022. } \\
\\
\text { DOI: } \\
\text { 10.28946/slrev.Vol6.Iss1. } \\
\text { 928.pp101-121 }\end{array}$ & $\begin{array}{l}\text { The Indonesian bankruptcy regime tends to be harsh to the debtors, especial- } \\
\text { ly the individual debtors. In contrast, the creditors possess the right to pursue } \\
\text { the debtor's outstanding debts even after the bankruptcy process. For that } \\
\text { reason, this article aims to argue why it is rational for the Indonesian gov- } \\
\text { ernment to implement a debt discharge policy in the Indonesian bankruptcy } \\
\text { regime. This article employs a normative research method, using a concep- } \\
\text { tual and comparative approach. The result of this study is based on the debt- } \\
\text { or cooperation theory and the humanitarian theory of debt discharge. Hence, } \\
\text { it is rational for the Indonesian government to implement a debt discharge } \\
\text { policy for individual debtors. The first and second Sila of Pancasila is also } \\
\text { in line with these theories. Consequently, as a member of society, the indi- } \\
\text { vidual debtor should be treated with dignity and humane values, which in- } \\
\text { cludes debt forgiveness. Nevertheless, not every debtor is deserves to be dis- } \\
\text { charged from his debts. Therefore, it is rational for the Indonesian govern- } \\
\text { ment to implement the debt discharge policy in the amendment of Indone- } \\
\text { sian bankruptcy law to protect the honest but unfortunate individual debtors. }\end{array}$ \\
\hline
\end{tabular}

\section{INTRODUCTION}

Indonesian bankruptcy regime tends to be harsh and does not provide sufficient legal protection on the debtors, in this case, individual debtors. According to the historical fact, it is undisputed that bankruptcy law was admittedly intended to provide debtors unrelenting treatments in the early time. ${ }^{1}$ The bankrupts were treated punitively. For example, the debtors might be stripped off from all of their assets without any exemptions, the revocation of citizenship, sold as enslaved people, imprisonment or even worse, the death penalty. ${ }^{2}$ During the development, bank-

1 Charles Jordan Tabb, "The History of the Bankruptcy Laws in the United States," American Bankruptcy Institute Law Review 3 (1995): 5-51.

2 Rafael Efrat, “The Evolution of Bankruptcy Stigma,” Theoretical Inquiries in Law 7, no. 1 (2006): 364-93. 
ruptcy law does no longer viewed as a mechanism to punish or humiliate the debtors. ${ }^{3}$ Since the early $19^{\text {th }}$ century, bankruptcy law has been viewed as a solution to financial distress which is faced by debtors from diverse classes, whether the debtor was a huge corporation or a mere individual. ${ }^{4}$ For instance, in the United States of America, since the 1960s bankruptcy system had been regarded as a legal protection system, as a part of the Federal Fresh Start Program (debt discharge), a wise financial strategy and as a simple settlement to temporary setbacks. ${ }^{5}$

The debt discharge principle is one of the universal bankruptcy principles recognised by most countries globally. ${ }^{6}$ Jackson argued that one of the advantages that bankruptcy law could offer to individual debtors is debt discharge. ${ }^{7}$ An individual debtor might be wiped off his leftover debts, which he cannot pay any more as long as the debtor does not break the existing bankruptcy law norms. ${ }^{8}$ Discharge bestows the freedom to an individual debtor from the restraints of his creditors so that he can return to the economic wheel, which to earn and consume. ${ }^{9}$

Gross stated: "For debtors, the ideal system provides a fresh start, premised on the recognition that mistakes happen, but debtors can be rehabilitated through forgiveness." ${ }^{10}$ In other words, a debt discharge principle is a form of the principle of balance that should be accommodated in a bankruptcy law system. The Indonesian bankruptcy law explicitly declares that the Indonesian bankruptcy regime has adhered to the principle of balance, which one of which is to provide debtor protection from bad faith creditors. ${ }^{11}$ Unfortunately, the Indonesian bankruptcy regime does not adhere to the debt discharge principle. ${ }^{12}$

The central issue lies in Article 204 Law No. 37 of 2004 on Bankruptcy and Suspension of the Payment, which states that after the distribution list becomes final and binding, the creditor repossesses the rights of enforcement against the debtor's assets to cover the unpaid claims. The creditors could still force the bankrupt individual debtors to satisfy the future's outstanding debts unless the creditors are satisfied with the fulfilment of the claims. ${ }^{13}$ This condition gives rise to legal uncertainty and unprotected rights of the individual bankrupts.

3 Kurnia Toha and Sonyendah Retnaningsih, "Legal Policy Granting Status of Fresh Start to the Individual Bankrupt Debtor in Developing the Bankruptcy Law in Indonesia," Academic Journal of Interdisciplinary Studies 9, no. 2 (2020): 157-61.

4 David A. Skeel Jr., "When Should Bankruptcy Be an Option (for People, Places, or Things)?," William \& Mary Law Review 55, no. 6 (2014): 2217-52.

5 Efrat, "The Evolution of Bankruptcy Stigma."

6 M.Hadi Shubhan, Hukum Kepailitan: Prinsip, Norma, Dan Praktik Di Pengadilan, 3rd ed. (Jakarta: Prenada Media, 2012).

7 Thomas H. Jackson, "The Fresh-Start Policy in Bankruptcy Law," Harvard Law Review 98 , no. 7 (1985): 1393-1448.

8 Jackson.

9 Richard E. Flint, "Bankruptcy Policy: Toward A Moral Justification for Financial Rehabilitation of the Consumer Debtor," Washington and Lee Law Review 48, no. 2 (1991): 515-77.

10 Karen Gross, Failure and Forgiveness: Rebalancing the Bankruptcy System (New Haven: Yale University Press, 1997).

11 Republik Indonesia, General Explanation of Law No. 37 of 2004 on Bankruptcy and Suspension of the Payment, $17^{\text {th }}$ Paragraph.

12 Sutan Remy Sjahdeini, Sejarah, Asas, Dan Teori Hukum Kepailitan: Memahami Undang-Undang Nomor 37 Tahun 2004 Tentang Kepailitan Dan Penundaan Kewajiban Pembayaran Utang, 2nd ed. (Jakarta: Prenada Media, 2016).

13 Republik Indonesia, Article 216 Law No. 37 of 2004 on Bankruptcy and Suspension of the Payment. 
There are two prior studies on debt discharge policy in Indonesia. First, the study that conducted by Ikhwansyah and Retnaningsih in 2017. This study describes the legal status of individual bankrupts' post-bankruptcy decision and the bankrupt individuals' outstanding debts under the Indonesian bankruptcy legal framework and vaguely argue the importance of providing a debt discharge policy for the individual debtors. Second, the study conducted by Toha and Retnaningsih in 2020 highlights that Indonesian bankruptcy law ought to adhere to debt discharge policy in order to grant a fresh start to the individual bankrupts as a part of bankruptcy law development in Indonesia. This study focused on the normative aspect and did not explain the theoretical foundations to support the claim. ${ }^{14}$ Both of these studies failed to argue and explain the theoretical foundations to justify the debt discharge policy in the Indonesian bankruptcy regime. Therefore, this article argues why it is essential for the Indonesian bankruptcy regime to adhere to the debt discharge policy for the individual debtors while analysing the theoretical foundations which support the claim.

To attain the aims, the article shall attempt to answer the following legal issues, which will be explained in the analysis and discussion section:1) What are the theoretical foundations that justify the debt discharge policy for the individual debtors? 2) How debt discharge policy for individual debtors is regulated in the United States of America, the United Kingdom, the Netherland and France bankruptcy systems? 3) What is the rationalisation to adopt a debt discharge policy in the Indonesian bankruptcy regime? 4) What are the restrictions of the debt discharge policy for the individual debtors?. Subsequently, the final section shall describe this article's conclusion and a closing statement.

\section{RESEARCH METHODS}

This article employs a normative research method by utilising a systematic study on Law No. 37 of 2004 on Bankruptcy and Suspension of the Payment, the United States Bankruptcy Code, Insolvency Act 1986, Insolvency Rules 2016, Netherlands Bankruptcy Code, French Consumer Code to examine how each law regulates the debt discharge for individual debtors.. ${ }^{15}$ The comparative approach is also utilised in this article to examine the development and regulation of the debt discharge policy in two common law countries: the United States of America and the United Kingdom, and two civil law countries, France and the Netherlands. ${ }^{16}$ This article also utilised a conceptual approach to analyse two theories to build a solid legal argument in rationalising the debt discharge policy in the Indonesian bankruptcy regime. ${ }^{17}$ The article utilised secondary data, which consists of primary legal materials, such as Law No. 37 of 2004 on Bankruptcy and Suspension of the Payment, the United States Bankruptcy Code, the United Kingdom Insolvency Act 1986, the United Kingdom Insolvency Rules 2016, the Netherlands Bankruptcy, and the French Consumer Code. The article also utilised secondary legal materials,

14 Toha and Retnaningsih, "Legal Policy Granting Status of Fresh Start to the Individual Bankrupt Debtor in Developing the Bankruptcy Law in Indonesia",. Sonyendah Retnaningsih and Isis Ikhwansyah, "Legal Status of Individual Bankrupt Debtors After Termination of Bankruptcy and Rehabilitation Under Indonesian Bankruptcy Law," Indonesia Law Review 7, no. 1 (2017): 79-93.

15 Anwarul Yaqin, Legal Research and Writing (Petaling Jaya: Dophin Press, Sdn. Bhd., 2007).

16 Konrad Zweigert and Hein Kotz, An Introduction to Comparative Law, Third (New York: Oxford University Press, 1998).

17 Peter Mahmud Marzuki, Penelitian Hukum, Revised (Jakarta: Prenada Media, 2013). 
such as books, scholarly articles, proceeding articles, and internet sources. The data required in this article were collected through the library study. The collected data will be processed and organised in a logical scheme to present the solution to this article's issue. ${ }^{18}$

\section{ANALYSIS AND DISCUSSION}

\section{Theoretical Foundations for Debt Discharge Policy}

\section{Debtor Cooperation Theory}

Tabb proposed the debtor cooperation theory. This theory provides a historical justification for the debt discharge policy. ${ }^{19}$ The theory asserted that debt discharge is based on a theory that discharge will inspire the debtor to act cooperatively in a bankruptcy process. ${ }^{20}$ Tabb provided a more detailed description of this theory. Tabb describes discharge as "carrot bound in front of a rabbit (the debtor)." Hence, the debtors are willing to collaborate with the trustee and the creditors to identify, collect and liquidate the debtors' assets in a bankruptcy process. ${ }^{21}$

There will always be a debtor in the business reality who drowned in an insolvency state because of pure bad luck or lousy business management. ${ }^{22}$ The first bankruptcy laws were harsh and provided a coercive debt collection method to the creditors. ${ }^{23}$ The harsh treatment towards debtors encourages them to devise numerous deceptive tactics, such as assets concealment or assets transfer to the third party, rendering other predicaments for the creditors in the debt collection process. $^{24}$

In its development, bankruptcy law was then designed based on a debtor's cooperative action toward his creditors while maximising their claims' fulfilment. ${ }^{25}$ If the debtor is proven to be dishonest and not cooperative, then the discharge shall not be granted. ${ }^{26}$ The possibility of achieving discharge gave the debtor incentive to surrender all of his assets to be redistributed among his creditors, which will maximise the debt recovery rate and decrease the bankruptcy administrative costs. ${ }^{27}$ The rationale of debt discharge has changed the main feature of bankruptcy law that stayed for around 200 years long which is utilised as a debt collection tool by the creditors into a system that provides debt relief for the debtors. ${ }^{28}$ This theory justifies the

18 Soetandyo Wignjosoebroto, Pedoman \& Tata Cara Penulisan Disertasi (Malang: Madani, 2017).

19 Michael D. Sousa, "The Principle of Consumer Utility: A Contemporary Theory of the Bankruptcy Discharge," Kansas Law Review 58, no. 3 (2010): 553-614.

20 Richard M. Hynes, “Why (Consumer) Bankruptcy?,” Alabama Law Review 56, no. 1 (2004): 121-79.

21 Charles Jordan Tabb, "The Scope of the Fresh Start in Bankruptcy: Collateral Conversions and the Dischargeability Debate," The George Washington Law Review 59, no. 1 (1990): 56-113.

22 Ralph C McCullough, "Bankruptcy Fraud: Crime without Punishment II," Commercial Law Journal 102, no. 1 (1997): 1-54.

23 McCullough.

24 John King, 'Moving Beyond the 'Hard'-'Easy' Tug of War: A Historical, Empirical and Theoretical Assessment of Bankruptcy Discharge," Melbourne University Law Review 28, no. 3 (2004): 654-89.

25 John C. McCoid, "Discharge: The Most Important Development in Bankruptcy History," American Bankruptcy Law Journal 70, no. 2 (1996): 163-94.

26 Tabb, "The Scope of the Fresh Start in Bankruptcy: Collateral Conversions and the Dischargeability Debate."

27 King, "Moving Beyond the 'Hard'-'Easy' Tug of War: A Historical, Empirical and Theoretical Assessment of Bankruptcy Discharge."

28 Charles Jordan Tabb, "The Historical Evolution of the Bankruptcy Discharge," American Bankruptcy Law Journal 65, no. 1 (1991): 325-71. 
discharge delay or even denial of discharge for the non-compliance debtors. An "carrot and rabbit" approach tends to improve the debtors' cooperative rate in bankruptcy processes. ${ }^{29}$

\section{The Humanitarian Theory of Debt Discharge}

Karen Gross and Richard introduced the humanitarian theory of debt discharge. E Flint. This theory emphasises the notion of rehabilitation and demonstration of mercy toward the individual debtors as a reasonable justification for granting debt discharge.$^{30}$ According to Gross, a debt discharge is considered appropriate if these four preconditions are satisfied: 1) There must be a wrong committed by the debtor, which fails to fulfil his/her financial obligations, 2) The debtor's failure to fulfil his/her financial obligations caused harm to the creditors, 3) The creditors resent the debtor's failure to honour his/her financial obligations, 4) The debtor admitted his/her wrongdoing and accessing the bankruptcy system as a step to rectify his/her mistake. ${ }^{31}$

Subsequently, Gross argued, the debt discharge renders a restorative function for both the debtors and creditors. The debtor that had applied for bankruptcy petition will face the consequences in scrutiny of all his/her private and financial affairs. This condition will enable the creditors "to feel that the disequilibrium created by non-payment has been at least partially restored." ${ }^{32}$ Gross then explained that the bankruptcy process's transformative power provides the debtors with an opportunity to reclaim self-esteem and recover as productive members of society. ${ }^{33}$ Debtors' rehabilitation is a part of the responsibility of treating the member of society humanely. Debt discharge promotes self-respect values; therefore, if the debtors are treated with the motives of retaliation and retribution, this does not indicate respect or humane values. ${ }^{34}$

Flint provides a more profound view regarding the humanitarian theory. Flint's viewpoint of this theory was based on the morality theory of natural law. ${ }^{35}$ According to Flint, the bankruptcy law has evolved from "one retaliation and punishment, to compensation for creditors, to compassion and concern for the less fortunate in our society." ${ }^{36}$ It was stated that the moral responsibility of the society to assist the debtor drowned in profound financial distress is more meaningful than the debtor's moral responsibility to resolve his financial obligations. ${ }^{37}$ If a debtor was left in a bankruptcy state without discharge, then the debtor will lose his right to enjoy his earnings and to sue for personal wrongs except for the interest of the bankruptcy estate. ${ }^{38}$ This condition will only make a debtor look like a fugitive, a bondservant to the trustees, contrary to natural justice. ${ }^{39}$

\footnotetext{
29 King, "Moving Beyond the 'Hard'-'Easy' Tug of War: A Historical, Empirical and Theoretical Assessment of Bankruptcy Discharge."

30 Sousa, "The Principle of Consumer Utility: A Contemporary Theory of the Bankruptcy Discharge."

31 Gross, Failure and Forgiveness: Rebalancing the Bankruptcy System.

32 Gross.

33 Gross.

34 Gross.

35 Flint, "Bankruptcy Policy: Toward A Moral Justification for Financial Rehabilitation of the Consumer Debtor."

36 Flint.

37 Philip Shuchman, "An Attempt at a Philosophy of Bankruptcy," UCLA Law Review 21, no. 2 (1973): 403-76.

38 Adam J. Hirsch, "Inheritance and Bankruptcy: The Meaning of the 'Fresh Start,"' Hastings Law Journal 45, no. 2 (1994): 175-248.

39 John Finnis, Natural Law \& Natural Rights, 2nd ed. (New York: Oxford University Press, 2011).
} 
The debt discharge process could also be comprehended as an acknowledgement from the legislator regarding the intrinsic value of human dignity, which implies a debtor should be allowed to earn a living once again. ${ }^{40}$ Discharging a debtor from his debt burdens allows him to maintain the minimum standard of living and sets him back on a route to self-determination. Therefore, the legislator viewed the discharge as a sign that human dignity has value. ${ }^{41}$ Releasing a debtor from the shackles of debt could be considered as a morally equitable response to the suffering of an honest but unfortunate person. ${ }^{42}$ Morality and basic humanity expect the law to exhibit compassion and mercy towards the pointless suffering of a debtor. ${ }^{43}$ Thus, Thomas Aquinas stated that humans have eternal reasons to dissociate evil and good. ${ }^{44}$ The ending of a debtor's pointless suffering by providing debt discharge is considered as one of many good actions to do by a human.

\section{Existing Condition in Indonesian Bankruptcy Regime Regarding Individual Bankrupt Status}

The current Indonesian bankruptcy regime does not distinguish the bankruptcy proceedings either for individual or legal entity debtors (corporate debtors). Indonesian bankruptcy law defines a debtor as "a person who possesses debt because of agreements or by law which its satisfaction can be enforced in front of the court." ${ }^{45}$ The phrase "person" in jurisprudence could be interpreted as a legal subject, either an individual or a legal person. ${ }^{46}$ In other words, any kind of debtor is going through the same process in the Indonesian bankruptcy regime. This will bring identical legal consequences to both individual or legal entity debtors post-bankruptcy proceedings.

The Indonesian bankruptcy regime adheres to the collective debt claim principle by providing general seizure to all debtors' assets as a payment guarantee towards the creditors' claims. ${ }^{47}$ Bankruptcy law ensures a mechanism that prevents the creditors' race individually from collecting their claims to the debtor. This kind of debt collection, while harming the creditors' interest, is also ineffective and inefficient. ${ }^{48}$ The bankruptcy law in Indonesia is merely regarded as a tool for creditors to enforce claims from their debtor, either individual debtors or legal entity debtors, by liquidating their assets as a means of payment. ${ }^{49}$

In the Indonesian bankruptcy regime, if a debtor has been announced bankrupt by the court, the debtor will subsequently lose all the rights on his assets. ${ }^{50}$ The trustee will take over the control of the bankruptcy estate under the supervision of the appointed judge. The bankruptcy estate will be auctioned, and the outcome will be distributed among the creditors accord-

\footnotetext{
40 Flint, "Bankruptcy Policy: Toward A Moral Justification for Financial Rehabilitation of the Consumer Debtor."

41 Flint.

42 Jason J. Kilborn, "Mercy, Rehabilitation, and Quid Pro Quo: A Radical Reassessment of Individual Bankruptcy," Ohio State Law Journal 64, no. 3 (2003): 855-96.

43 Kilborn.

44 Suri Ratnapala, Jurisprudence (Melbourne: Cambridge University Press, 2009).

45 Republik Indonesia, Article 1, Number 3, Law No. 37 of 2004 on Bankruptcy and Suspension of the Payment.

46 R Soeroso, Pengantar Ilmu Hukum (Jakarta: Sinar Grafika, 2017).

47 Shubhan, Hukum Kepailitan: Prinsip, Norma, Dan Praktik Di Pengadilan.

48 Thomas H. Jackson, The Logic and Limits of Bankruptcy Law (Washington D.C.: BeardBooks, 2001).

49 Shubhan, Hukum Kepailitan: Prinsip, Norma, Dan Praktik Di Pengadilan.

50 Republik Indonesia, Article 21 Law No. 37 of 2004 on Bankruptcy and Suspension of the Payment.
} 
ing to the pari passu ${ }^{51}$ pro rata parte ${ }^{52}$ principle. Article 204 Law No. 37 of 2004 on Bankruptcy and Suspension of Payments states that after the closing assets distribution list becomes final and binding, the creditors reobtain the right to enforce the debtor's outstanding debts. Boldly saying, if a debtor still possesses debts to his creditors' post-bankruptcy process, the creditors still possess the right to claim the remaining debts. This condition will indeed render it difficult for individual debtors to raise back from financial difficulties because sometime in the future, their creditors might attempt to claim the remaining debts. Even worse, the particular debtor could be declared bankrupt by the court for the second time if the creditors are willing. ${ }^{53}$

A different situation exists for legal entity debtors. If the debtor's assets are not sufficient to compensate its debts, then by law, the debtor will be dissolved. ${ }^{54}$ Thus, the debtor does not need to bear any responsibility for the outstanding debts. ${ }^{55}$ This circumstance will promote injustice and does not provide adequate protection for the interest of individual debtors. In its nature, individual bankruptcy has two aspects: the debtor's assets and the individual debtor himself. ${ }^{56}$ An individual debtor in the bankruptcy process ought to let go of his assets while given an opportunity to defend his dignity as a human by obtaining debt discharge. ${ }^{57}$

Unfortunately, the Indonesian bankruptcy regime does not consider an individual debtor as humankind whose dignity ought to be preserved; in contrast, what is considered essential in the Indonesian bankruptcy regime is merely the debtor's assets for his creditors' interest. This matter conflicts with the moral value of natural law and the principle of balance, which is the Indonesian bankruptcy regime adhered to. If a legal entity debtor is dissolved by law because it cannot resolve its outstanding debts, the individual debtor should be awarded the same opportunity. The referred opportunity is by providing debt discharge for the individual debtors.

\section{Debt Discharge Policy in Several Jurisdictions}

This section shall compare and describe the debt discharge policy in several jurisdictions. The chosen countries are two countries from common law tradition and two countries from civil law tradition, namely the United States of America, United Kingdom, Netherlands, and France. The following comparison is made to present a comprehensive overview of the debt discharge policy in these comparison countries.

\section{United States of America}

The debtors in the United States are entitled to exercise several bankruptcy procedures regulated in Title 11 of the United States Code (The Bankruptcy Code), i.e., Chapter 7, 11, 12, and 13. ${ }^{58}$ The general procedure for individual debtors is in Chapters 7,12 , and 13. Chapter 11 is a reorganisation procedure specially designed for corporate debtors who are currently in financial

51 Republik Indonesia, Article 1131 "Indonesian Civil Code".

52 Republik Indonesia, Article 1132 "Indonesian Civil Code".

53 Gunawan Widjaja, Seri Hukum Bisnis: Daluwarsa (Jakarta: RajaGrafindo Persada, 2005).

54 Republik Indonesia, Article 142, paragrahp 1, letter d, Law No. 40 of 2007 on Limited Liability Company (2007).

55 Zaeni Asyhadie and Budi Sutrisno, Hukum Perusahaan \& Kepailitan (Jakarta: Erlangga, 2012).

56 Donald R. Korobkin, "Rehabilitating Values: A Jurisprudence of Bankruptcy," Columbia Law Review 91 , no. 4 (1991): 717-89.

57 Korobkin.

58 Stephen R. Elias, The New Bankruptcy: Will It Work for You?, 4th ed. (California: NOLO, 2011). 
distress. Chapter 7 is a liquidation procedure in which an individual debtor honestly exposed all of his assets and financial affairs to the court in the hope of obtaining legal protection in the form of automatic stay and discharge. ${ }^{59}$ Chapter 12 and 13 are reorganisation procedures for individual debtors, while Chapter 12 is designed especially for farmer and fisherman debtors. ${ }^{60}$

Essentially, Chapters 7, 11, 12, and 13 have their specific discharge regulations. ${ }^{61}$ In order to provide a more focused insight, this section shall discuss only Chapter 7 discharge. Chapter 7 is commenced by an individual debtor who filed a bankruptcy petition to the court, which jurisdiction includes the debtor's domicile. The debtor must include assets, debts, income, current expenditure statements, and ongoing sale and lease contracts in his bankruptcy petition. ${ }^{62} \mathrm{Be}-$ sides, the debtor must also attach the proof of credit counselling participation, which originates from a certificate granted to a debtor after completing credit counselling. ${ }^{63}$ After the debtor files his petition to the court, the debtor shall be granted an automatic stay. ${ }^{64}$ The law does not justify every attempt from the creditors to collect, harass, or even seizure the debtor's assets in this stay period. ${ }^{65}$

In the span of 30 days since the date of the Chapter 7 petition was filed, the debtor shall be summoned by the court to attend the creditors' meeting known as the "341 hearing". ${ }^{66}$ The debtor's honesty and accurate information in his petition, including the attached statements, is the main reason the creditors' meeting is held. ${ }^{67}$ In the span of 60-90 days since the filing date and there is no objection from the third party or the creditors, the court will provide discharge to all of the debtor's debts before the discharge award date. ${ }^{68}$ Therefore, the creditors are not allowed to collect the discharged debts, and the debtor gained another opportunity to raise back and participate in the economic wheel.

The immediate discharge is like a two-edged sword. On one side, it might help the honest but unfortunate debtors. On the other side, it might be abused by dishonest debtors. The sly debtors would abuse the discharge feature to escape their liabilities toward the creditors. In April 2005, the United States President signed Bankruptcy Abuse Prevention and Customer Protection Act (BAPCPA) into effective law. ${ }^{69}$ The reason for this enactment was to prevent debtor abuses arising from the 1978 United States bankruptcy law reform. ${ }^{70}$ The exclusive feature of BAPCPA is the "means test". The means test was implemented to restrict eligibility for discharge under Chapter 7 and force the debtors to go for Chapter 13 procedures. ${ }^{71}$

\footnotetext{
59 Joan N. Feeney and Theodore W. Connoly, The Road Out of Debt: Bankruptcy and Other Solutions to Your Financial Problems (New Jersey: John Wiley \& Sons, Inc., 2010).

60 Elias, The New Bankruptcy: Will It Work for You?

61 Robert L. Jordan and William D. Warren, Bankruptcy, 3rd ed. (New York: The Foundation Press, Inc., 1993).

62 United States Courts, "Chapter 7 - Bankruptcy Basics," 2020, https://www.uscourts.gov/servicesforms/bankruptcy/bankruptcy-basics/chapter-7-bankruptcy-basics.

63 Elias, The New Bankruptcy: Will It Work for You?

64 Elias.

65 Jordan and Warren, Bankruptcy.

66 Elias, The New Bankruptcy: Will It Work for You?

67 Elias.

68 Elias.

69 Sousa, "The Principle of Consumer Utility: A Contemporary Theory of the Bankruptcy Discharge."

70 Sousa.

71 Sousa.
} 
If a debtor's current monthly income is higher than the state's median income while the debtor is filing for a Chapter 7 procedure, the debtor must take the means test. ${ }^{72}$ he means test measures specific expenses and deductions such as tax against a debtor's current monthly income. The test was done to determine whether the debtor holds extra income to propose a Chapter 13 plan. In other words, the means test determines whether a "presumption of abuse" rises or not in a Chapter 7 petition. By law, any debtor who filed for Chapter 7 would be presumed to be abusing the bankruptcy system until proven otherwise. ${ }^{73}$ If the debtor failed in the means test, the Chapter 7 petition might be dismissed or converted to the Chapter 13 procedure on the debtor's consent.

\section{The United Kingdom (England and Wales)}

Bankruptcy in the UK basically can be distinguished into corporate and individual bankruptcy. At first, the Insolvency Act 1986 and Insolvency Rules 2016 (which repealed Insolvency Rules 1986) were efforts from the UK government to harmonise between individual and corporate bankruptcy provisions. ${ }^{74}$ However, since 2020, the UK Parliament has issued CIGA (Corporate Insolvency and Governance Act), similar to the United States' Chapter $11 .{ }^{75}$ CIGA amends several provisions in Insolvency Act 1986 dan Company Act 2006. It is evident because CIGA was intended for corporate bankruptcy matters.

The UK bankruptcy regime recognises three methods for individual bankruptcy, which are Bankruptcy, Debt Relief Order (DRO), and (Individual Voluntary Arrangement (IVA). ${ }^{76}$ Bankruptcy is a process where an insolvent individual debtor surrenders all of his assets and income to obtain a discharge from all of his prevailing debts. DRO is a procedure similar to bankruptcy, but it is intended for the extremely poor debtor, which held unsecured debts below 20.000 GBP and was never involved in a business transaction in the last two years. ${ }^{77}$ IVA is a procedure similar to the United States' Chapter 13, in which an individual debtor negotiates with his creditors regarding his debt restructure. ${ }^{78}$

The individual debtor who seemed overburdened by his debts may file an online bankruptcy petition. An adjudicator from the Insolvency Service under the UK government will process the petition and determine whether the petition is accepted or declined. ${ }^{79}$ The debtor will not be granted an immediate discharge if the petition is accepted, such as in the US's Chapter 7 process. Instead, there is a waiting period of one year before the discharge is granted. ${ }^{80}$ Although

72 Elias, The New Bankruptcy: Will It Work for You?

73 Elias.

74 David Milman and Chris Durrant, Corporate Insolvency: Law and Practice (London: Sweet \& Maxwell, 1999).

75 Morgan Lewis \& Bockius LLP, "Strange Effects of the UK's New Insolvency Law," 2020, https://www.lexology.com/library/detail.aspx?g=29cec1a0-5c67-472f-9b5e-bd9866bf7a02.

76 Joseph Spooner, "Explaining Personal Insolvency and the Law," 2020, https://www.law.ox.ac.uk/housingafter-grenfell/blog/2020/07/explaining-personal-insolvency-and-law.

77 Iain Ramsay, “The New Poor Person's Bankruptcy: Comparative Perspectives," International Insolvency Review 29, no. 1 (2020): 4-24.

78 Spooner, "Explaining Personal Insolvency and the Law."

79 Spooner.

80 Ruzita Azmi, Adilah Abdul Razak, and Siti Nur Samawati Ahmad, "Discharge in Bankruptcy: A Comparative Analysis of Law and Practice Between Malaysia, Singapore and the United Kingdom (UK) - What Can We Learn?," Commonwealth Law Bulletin 43, no. 2 (2017): 203-33. 
the debtor has obtained debt discharge, there is a possibility that the debtor is obliged to pay his remaining debts to his creditors for three years. If the debtors held any surplus income, then based on the Income Payment Order or Income Payment Agreement, the remaining debts must be settled according to the agreement for at least three years. However, in reality, the financial position of the discharged debtors is frail. Only about $15-20 \%$ of the debtors hold surplus income to resolve their remaining debts. ${ }^{81}$

\section{The Netherlands}

The Netherlands bankruptcy regime contains some similarities with the Indonesian bankruptcy regime. The similarities result from the historical fact that the Indonesian bankruptcy law is a legacy from the bankruptcy law employed in the Dutch colonialism era in Indonesia back to the $18-19^{\text {th }}$ century. ${ }^{82}$ Both Netherlands and Indonesia bankruptcy regimes recognise Bankruptcy and Suspension of the Debt Payment Obligation procedures. The difference between the Netherlands and Indonesian bankruptcy regimes lies in the individual bankruptcy procedure. Since 1998, the Netherlands government has regulated the Debt Restructuring Procedure for Individual Debtors (Wet Schuldsanering Natuurlijke Personen, "Wnsp") in the Netherlands bankruptcy regime. Wnsp is regulated under Chapter 3 of the Netherlands Bankruptcy Code.

The court may grant debt discharge to an individual debtor who holds good faith yet cannot repay his prevailing debts to his creditors. ${ }^{83}$ An individual debtor, sole trader, a partner in a partnership, or a freelancer who is unable to pay all of his debts may file for debt restructuring in two ways: First, the debtor may file for a debt restructuring procedure provided by the Debt Restructuring Facility in his municipality. Second, the debtor may file for a debt restructuring procedure to the court, with help from a debt restructuring counsellor or a lawyer. ${ }^{84}$

The requirements for a debtor to obtain Wnsp are as follows: ${ }^{85}$ 1) The debtor has acquired a written statement from the debt restructuring counsellor in the municipality or a Wnsp lawyer, stating that his voluntary debt restructuring had failed. 2) The debtor has not filed for Wnsp for the last ten years. 3) The debtor did not induce his debts from fine, fraud, or reckless spending for the last five years, and the debtors must be deemed administrative appropriate. 4) The debtor did not hold debts that arise from criminal activities. 5) The debtor committed to gaining as much income as possible to repay his debts.

If the fore-mentioned requirements are examined thoroughly, it could be inferred that honesty and good faith from the debtor become an essential indicator in determining a Wnsp procedure's success. If a Wnsp is granted, the debtor will adhere to a strict debt repayment plan for three to five years. ${ }^{86}$ The debtor must work or find a job to earn income in order to repay his

81 Spooner, "Explaining Personal Insolvency and the Law."

82 Sjahdeini, Sejarah, Asas, Dan Teori Hukum Kepailitan: Memahami Undang-Undang Nomor 37 Tahun 2004 Tentang Kepailitan Dan Penundaan Kewajiban Pembayaran Utang.

83 Siti Anisah, "Studi Komparasi Terhadap Perlindungan Kepentingan Kreditor Dan Debitor Dalam Hukum Kepailitan," Jurnal Hukum 16, no. Edisi Khusus (2009): 30-50.

84 Bos van der Burg Advocaten, "Debt Restructuring for Self-Employed Professionals in the Netherlands," International Network of Law and Consulting Firms, 2019, https://pragma.international/article/debtrestructuring-for-self-employed-professionals-in-the-netherlands.

85 Bos van der Burg Advocaten.

86 Netherlands Enterprise Agency, "Debt Restructuring," Business.gov.nl, accessed November 29, 2020, https://business.gov.nl/regulation/debt-restructuring/. 
restructured debts. The Wnsp administrator will calculate the amount of income that the debtor may keep for his living expenses. The remaining income will be used to repay the creditors. ${ }^{87}$ The debtor is not authorised to create new debts during this procedure. The judge would award him a debt discharge if the debtor succeeded in satisfying all of his Wnsp obligations (also known as "schone lei"). The debtor is no longer compelled to satisfy his outstanding debts. ${ }^{88}$

\section{France}

France's bankruptcy regime distinguishes bankruptcy procedures for individuals and corporations. The individual bankruptcy procedure is governed under Article L33-1 of the French Consumer Code. In contrast, the corporation bankruptcy procedure is governed under the Book VI of the Commercial Code (Des Enterprises en Difficultes). ${ }^{89}$ Initially, France's individual bankruptcy regime was processed through court proceedings. This kind of system caused difficulties in the coordination among the creditors. Since 1989, France government has introduced an administrative instrument that functions besides the current legal system to assist the individual who suffers from over-indebtedness. The system's core is the Departmental Commissions for Over-indebted Individuals, an institution under the France Central Bank. ${ }^{90}$ This Commission was established to decrease the courts' workload in terms of bankruptcy cases. ${ }^{91}$

The individual debtors must deliver truthful information to the Commission regarding their assets and financial affairs. The Commission will then perform an inquiry on the debtor's petition for a maximum period of three months. ${ }^{92}$ The Commission possesses the authority to suspend the debtor's obligation to settle his or her debts for up to one year. The Commission may also order to reschedule the debtor's debts and adjust the interest rate. The Commission may only recommend a payment plan. If both debtor and creditors do not agree on the payment plan, the case will be submitted to a judge. The judge holds the authority to force the Commission's recommendation to the party or design a new payment scheme. ${ }^{93}$ When filing the petition to the Commission, the debtor's good faith presents an important role. The Commission reserves the right to decline a petition from the debtor if it is indicated that the debtor holds lousy faith. ${ }^{94}$

Suppose the debtor suddenly cannot live up to the plan expectation during the payment plan exercise. In that case, the Commission can recommend a debt discharge without liquidation or a debt discharge followed by a liquidation if the debtor's assets are enough for his debts. These conditions will eventually lead to suspending the creditors' collection rights to the debtor and wiping out all of the debtor's non-professional debts. ${ }^{95}$

87 Netherlands Enterprise Agency.

88 Bos van der Burg Advocaten, "Debt Restructuring for Self-Employed Professionals in the Netherlands."

89 Backer McKenzie, “Global Restructuring \& Insolvency Guide,” 2016, http://restructuring.bakermckenzie. com/wp-content/uploads/sites/23/2016/12/Global-Restructuring-Insolvency-Guide-New-Logo-France.pdf.

90 Gunnar Trumbull, "Consumer Protection in French and British Credit Markets," 2008, https://www.jchs. harvard.edu/sites/default/files/media/imp/ucc08-17_trumbull.pdf.

91 Jason J. Kilborn, “La Responsabilisation de L'economie: What the United States Can Learn from the New French Law on Consumer Overindebtedness," Michigan Journal of International Law 26, no. 2 (2005): 61971.

92 Backer McKenzie, "Global Restructuring \& Insolvency Guide.”

93 Trumbull, "Consumer Protection in French and British Credit Markets."

94 Trumbull.

95 Backer McKenzie, "Global Restructuring \& Insolvency Guide.” 
Based on the comparison description above, it could be inferred that countries with common law traditions such as the US and UK tend to operate the individual bankruptcy procedure by the courts. In contrast, countries with civil law traditions such as the Netherlands and France tend to hold the individual bankruptcy procedure by an institution outside the judicial power. UK, Netherlands and France do not implement immediate discharge to the debtors. The debtors must exhibit a best effort to repay their debts to the creditors in a certain period before the debts are finally discharged. The non-existence of immediate discharge procedures in the UK, Netherlands and France is because of the strong influence of the pacta sunt servanda principle in Europe. A contractual relationship that the party has agreed upon must be honoured and performed in good faith, which is a moral duty to keep their promises. ${ }^{96}$ It will not be fair for the creditors if their debt is discharged immediately without any attempts to repay the debt. The debtor's best effort to repay his debts before obtaining debt discharge is a sign of good faith and honour in the contractual relationship with the creditors.

\section{Rationalisation of Debt Discharge Policy in Indonesian Bankruptcy Regime}

Besides the collection purposes, bankruptcy law has developed an extra purpose. That purpose is the rehabilitative purpose of a debtor. This rehabilitative purpose is morally justified from the viewpoint of the humanitarian theory of debt discharge. From a moral point of view, the debt discharge of a debtor holds two different sides but is interconnected. First, it is about the commitment of society to a debtor. Second, it is about the commitment of a debtor to society. ${ }^{97}$ The commitment of the debtor and society depends on each other. Society is a group of individuals; thus, society's well-being depends on the well-being of the individuals who are part of it. Individual debtors must respect their financial obligation to society. The debtor's failure or unwillingness to pay his or her debts will hurt the creditors' well-being, who is also a part of society. Unfortunately, not every debtor possesses the capacity to fulfil their financial obligations without facing any struggles. If a debtor's well-being decreases, then the society's well-being where that debtor ensconces is also decreased. ${ }^{98}$ Therefore, society ought to help its member who is suffering from difficulties. This obligation is morally justified by humanitarian theory. If an individual debtor is suffering from financial distress, society's help provides a debt discharge.

Consequently, a complete understanding of a debtor's debt discharge's moral dimension may guide a moral justification of debt discharge policy in a bankruptcy regime. ${ }^{99}$ Suppose someone has understood the moral dimension of a matter. In that case, the person is believed to employ natural law methods by utilising morality principles to determine numerous choices of a collection of human virtue and values. ${ }^{100}$ Moral thinking obliges someone when he is about to justify an action; the person must connect the action with a principle or value, which becomes

\footnotetext{
96 Jukka Kilpi, The Ethics of Bankruptcy (New York: Routledge, 1998).

97 Flint, "Bankruptcy Policy: Toward A Moral Justification for Financial Rehabilitation of the Consumer Debtor."

98 Flint.

99 Flint.

100 Finnis, Natural Law \& Natural Rights.
} 
the main reason for the justification. ${ }^{101}$ Hence, if a debt discharge is morally approved, there must be a value that justifies it.

Humans are autonomous agents, which means humans are filled with free will. A debtor's promise to repay his debts is a part of this free will. ${ }^{102}$ The debtor's autonomy indicates that the debtor has a prima facie moral duty to keep his promises to settle debts. ${ }^{103}$ When a debtor goes insolvent, the debtor has lost his prima facie duty to perform his obligation. An insolvent debtor does not possess any moral obligation to repay his debts; therefore, the debtor will not commit any moral wrong. ${ }^{104}$ The termination of moral duty must be acknowledged by revoking any legal actions to enforce the moral duty. This revocation can be accomplished by the debt discharge policy as an instrument to revive the autonomy of a debtor. ${ }^{105}$

Debt discharge for an individual debtor in the Indonesian bankruptcy regime can be justified, especially if inspected from Pancasila's perspective as Indonesia's philosophical basis. ${ }^{106}$ If one pays close attention, the theory of humanitarian debt discharge is in line with Pancasila's second Sila, which states "Just and Civilised Humanity" (Kemanusiaan yang Adil dan Be$r a d a b)$. The second sila, which carries humanity's value, expects every Indonesian person to be civilised to carry out humanity's purpose optimally. ${ }^{107}$ Pancasila expects every Indonesian person not to be an individualistic or socialist man, but as a "monodualist" man. It means that Indonesia acknowledges humans as both individualist and socialist creatures in harmony, balance, and congenial. ${ }^{108}$ Every action of humankind must be just and humane towards himself, others, and God.

Indonesia places civilised and just human values as its philosophical basis; therefore, it will bring a consequence. The consequence is that every state administration will assure to exercise the value of humanity. The value of humanity involves recognising and realising human dignity, human rights, and human freedom. ${ }^{109}$ Every human action in the Pancasila view must be just by giving himself and others what is appropriate and entitled. ${ }^{110}$ Human is God's most perfect creation. Human perfection lies within civilised acts based on moral principles. ${ }^{111}$

In the case of debt and human rights, Article 19 paragraph (1) Law No. 39 of 1999 on Human Rights states that no offence or crime of any kind is punishable by the confiscation of all convicted property. Article 19 paragraph (2) states that nobody by a court decision may be sentenced to imprisonment based on the inability to fulfil a debt obligation. The article has re-

${ }^{101}$ Flint, "Bankruptcy Policy: Toward A Moral Justification for Financial Rehabilitation of the Consumer Debtor."

102 Kilpi, The Ethics of Bankruptcy.

${ }^{103}$ Kilpi.

${ }^{104}$ Kilpi.

${ }^{105}$ Kilpi.

${ }^{106}$ Kaelan, The Philosophy of Pancasila: The Way of Life of Indonesian Nation (Yogyakarta: Paradigma Press, 2014).

${ }^{107}$ Kaelan, Negara Kebangsaan Pancasila: Kultural, Historis, Filosofis, Yuridis Dan Aktualisasinya (Yogyakarta: Paradigma Press, 2013).

108 Kaelan.

${ }^{109}$ Heri Herdiawanto, Fokky Fuad Wasitaatmadja, and Jumanta Hamdayama, Spiritualisme Pancasila (Jakarta: Prenada Media, 2018).

${ }^{110}$ Kaelan, The Philosophy of Pancasila: The Way of Life of Indonesian Nation.

${ }^{111}$ Kaelan, Etika Kehidupan Berbangsa: Prinsip-Prinsip Etika Dalam Kehidupan Berbangsa Dan Bernegara Berdasarkan Pancasila (Yogyakarta: Paradigma Press, 2018). 
vealed that the Indonesian government has acknowledged the fundamental human right of freedom, including freedom of over-indebtedness and the opportunity to earn a living. In relation to bankruptcy, if an individual debtor cannot afford to settle his debts, the creditors should perform their best to relieve the debtor's burden as a member of society. The debtor's burden easing can be accomplished by administering debt restructuring and, finally, debt discharge.

Based on the debtor cooperation theory, as a member of society, the debtor should attempt his best to satisfy his financial obligations to the creditors, who are also society members. If the debtor has sought his best to settle his debts, but there are still outstanding debts, then it became the creditors' moral obligation as the members of society to forgive the debtor by providing debt discharge. This way, the debtor will be able to earn a decent living and return as a productive member of society, which will increase society's overall well-being. ${ }^{112}$ The discharge could be regarded as a reward for the debtor's honesty and earnest efforts to satisfy his debts as considerably as possible.

The just and civilised humanity continues the principle of Belief in the One and Only God, the first sila of Pancasila. ${ }^{113}$ Human behaviours toward others must also be just according to religious values. Indonesia's majority population is Muslim. ${ }^{114}$ Islam teachings, like other teachings, does include legal aspects. ${ }^{115}$ One of the legal aspects of Islamic law (sharia) is bankruptcy law. The basis for Islamic bankruptcy law lies in the QS Al-Baqarah 2:280. It was stated that: "and if the debtor is in straitened circumstances, then [let there be] postponement to [the time of] ease. Furthermore, if you give freely [i.e., voluntarily forgive the debt], it will be better for you, if you only knew". Many scholars regard this verse as the foundation of debt forgiveness in Islamic bankruptcy law. ${ }^{116}$

Ironically, this Islamic bankruptcy law value is not adopted in the Indonesian bankruptcy regime. This condition is in contrast to the humanitarian theory of debt discharge. The individual debtors in Indonesia are not treated with the value of dignity and humanity. Even the United States, as one of the most capitalistic nations globally, still acknowledged debt discharge policy to the individual debtors. Frankly speaking, Indonesia's bankruptcy regime that ought to origins from the Pancasila is harsher and more ruthless than the United States' bankruptcy regime. ${ }^{117}$ Based on the reasoning above, it is possible and rationale for the Indonesian government to acknowledge the debt discharge policy. The debt discharge policy will be in line with the Pancasila, particularly the first and the second sila.

To implement the debt discharge policy, Indonesia can learn from the Netherlands. Both Indonesia and the Netherlands share a similar bankruptcy regime. Indonesia needs to append

${ }^{112}$ Flint, "Bankruptcy Policy: Toward A Moral Justification for Financial Rehabilitation of the Consumer Debtor."

113 Yudi Latif, Negara Paripurna: Historisitas, Rasionalitas, Dan Aktualitas, 5th ed. (Jakarta: Gramedia Pustaka Utama, 2015).

114 Muhammad Daud Ali, Hukum Islam: Pengantar Ilmu Hukum Dan Tata Hukum Islam Di Indonesia (Jakarta: Rajawali Pers, 2009).

115 Siti Anisah, Perlindungan Kepentingan Kreditor Dan Debitor Dalam Hukum Kepailitan Di Indonesia (Yogyakarta: Total Media, 2008).

116 Jason J. Kilborn, "Foundation of Forgiveness in Islamic Bankruptcy Law: Sources, Methodology, Diversity," American Bankruptcy Law Journal 85 (2011): 323-54.

117 Robert and Bismar Nasution, "Adoption of Islamic Bankruptcy Law Values into Indonesian Bankruptcy Law to Protect Good Faith Debtors," in 1st International Conference on Law, Governance and Islamic Society (ICOLGIS 2019) (Banda Aceh: Atlantis Press, 2020), 157-61. 
individual bankruptcy procedures in its bankruptcy regime. The Indonesian government may establish a new institution in every municipality specialising in credit counselling and debt restructuring for individual debtors. If the debtor is proven to be honest and cooperative during the restructuring period, he or she may be discharged from all of the outstanding debts by the end of the period.

The proposed procedure will promote justice and legal certainty for the individual debtors who are honest yet unfortunate in the economic wheel. One may raise a question: why not award the individual debtors immediate discharge similar to the US bankruptcy regime? The immediate discharge is not a bad idea, but it must be exercised with extreme caution. A reckless immediate discharge will promote injustice for the creditors. The dishonest individual debtors might seek to abuse the system for getting away with the debts. The United States of America has learned this kind of abuse potential and employed means test for most debtors in Chapter 7, except the debtor's current monthly income is lower than the state's median income. This kind of procedure is quite complicated and is not easy to implement. Therefore, it is advised that the Indonesian government learn from the Netherlands' Wnsp procedure since it will promote justice for both debtors and creditors. It is also morally justified; the debtor will strive his best to honour his debts while the creditors also help relieve the debtor's burden because of overindebtedness.

\section{Limitation of The Debt Discharge Allowance}

It does not necessarily mean that every bankruptcy petition by the individual debtor must be awarded a debt discharged by the end of the procedure. Bankruptcy is supposed to be an instrument of forgiveness to the deserving debtors; instead, some debtors might utilise it as an instrument of abuse to avoid their financial obligations. ${ }^{118}$ King argued that if the procedure for obtaining a debt discharge is way too simple, then there are three potential methods of bankruptcy abuse by dishonest debtors. First, the debtors will file serial bankruptcy petitions. After the debtor obtains a debt discharge, he will try to file another petition soon after obtaining new debts. Second, the abuse from individual debtors that are still capable of settling their financial obligations; instead of paying their creditors directly, they opted for the bankruptcy procedure to settle the debts, which is unnecessary in this context. Third, the individual debtors borrowed money in a large sum then filed for bankruptcy in the hope to obtain a discharge and getting away with the large sum of money. ${ }^{119}$ Hence, the bankruptcy law should determine the criteria of an individual debtor that deserve for obtaining a debt discharge.

The main criteria of obtaining a debt discharge are concerning the debtor's honesty in a bankruptcy process. A debt discharge could be awarded to an honest debtor who discloses all of his financial affairs in most bankruptcy regimes. ${ }^{120}$ The United States Supreme Court in Local Loan v. Hunt ${ }^{121}$, stated that discharge should only be awarded to the honest yet unfortunate

\footnotetext{
118 Todd J. Zywicki, "Bankruptcy Law as Social Legislation,” Texas Review of Law \& Politics 5, no. 2 (2001): 132.

119 King, 'Moving Beyond the 'Hard'-'Easy' Tug of War: A Historical, Empirical and Theoretical Assessment of Bankruptcy Discharge."

${ }^{120}$ Richard B. Jacobson, "The Structure of Forgiveness," Cardozo Studies in Law and Literature 4, no. 2 (1992): $243-53$.

121 Local Loan Co. v. Hunt (292 U.S. 234) (1934).
} 
debtors. This decision is a precedent for numerous following cases. Therefore, every debt owed by an individual debtor through dishonest and fraudulent acts will not be discharged. ${ }^{122}$

Section 523 (a) of the United States Bankruptcy Code prescribes nine types of debt that are not dischargeable, which consist of: ${ }^{123}$ 1) Debts incurred by the tax; 2) The misleading statements by the debtor regarding his debts; 3) Debts that are not disclosed honestly by the debtor in his debt list; 4) Debts incurred from theft or embezzlement; 5) Debts incurred from the obligation of household sustenance; 6) Debts incurred from damages as the result of tortious acts; 7) Debts incurred from fines; 8) Debts incurred from student loans; 9) Debts that are not stated in the previous bankruptcy process.

As mentioned above, there are three generally accepted reasons why the debts will not be discharged. First, the debts raised from the debtor's acts are unaccepted by the social, moral and legal norms. Second, the debts involved a greater public interest than the debtor's interest. The third is the combination of the first and second reasons. ${ }^{124}$ In other words, debt discharge is not an absolute right of a debtor; instead, it depends on the debtor's honesty in the eve and during the bankruptcy process. ${ }^{125}$

Another reason that may cause the court to deny granting a debt discharge to the debtor is the illegal acts performed by the debtor before and during the bankruptcy process. For example, the debtor transferred or concealed his assets from the creditors during the bankruptcy process or in one year before the bankruptcy petition is registered to the court, the debtor transferred or destroyed his assets after the bankruptcy petition is registered to the court. The debtor's honesty regarding the information on his assets is also essential. The court may also deny a debt discharge award if the debtor forged, damaged, or destroyed his financial documents. The debtor delivers false testimony or presents a false witness regarding his bankruptcy case and the failure of the debtor to obey the court's order. ${ }^{126}$

According to the debtor's cooperation theory, the cooperative, honest debtors will be discharged of their outstanding debts. In contrast, dishonest debtors should be punished. Aside from being denied a discharge, the sly debtors must be subject to criminal sanctions such as imprisonment and fines. This view is in line with the reward and punishment concept. The abuse of the bankruptcy system by the debtor is a fraud to the court and the creditors. If the debtor's fraudulent acts remain unpunished, it will adversely affect the overall bankruptcy system. ${ }^{127}$

A bankruptcy fraud will bring at least three adverse consequences on the social and economic aspects if left unpunished, such as: ${ }^{128}$ 1) The government will have reduced tax revenue.

${ }^{122}$ Luther Zeigler, “The Fraud Exception to Discharge in Bankruptcy: A Reappraisal," Stanford Law Review 38, no. 3 (1986): 891-918.

123 Abbye Atkinson, “Consumer Bankruptcy, Nondischargeability, and Penal Debt," Vanderbilt Law Review 70, no. 3 (2017): 917-83.

124 Atkinson.

125 Michael D. Sousa, “A Delicate Balancing Act: Satisfying the Fourth Amendment While Protecting the Bankruptcy System from Debtor Fraud,” Yale Journal on Regulation 28, no. 2 (2011): 367-417.

126 Sousa.

${ }^{127}$ Leia A. Clement, "A Study on Bankruptcy Crime Prosecution under Title 18: Is the Process Undermining the Goals of the Bankruptcy System," Emory Bankruptcy Developments Journal 31, no. 2 (2015): 409-30.

${ }^{128}$ Nicole Forbes Stowell and Katherine Barker, "Fraud, Fraud, Fraud: Mortgage Fraud and Bankruptcy Fraud," Real Estate Review 40, no. 2 (2011): 47-62. 
2) The cost of credit becomes expensive. The creditors might develop a fear of the risk of being scammed by the debtor; the high-interest rate compensates for the high risk of credit; 3) Finally, unpunished bankruptcy fraud will decrease public confidence towards honesty and integrity of a bankruptcy system.

Consequently, legal provisions that punish an individual debtor who attempts to abuse a bankruptcy system are indispensable features of a bankruptcy regime. ${ }^{129}$ The Indonesian government has to ascertain that before implementing the debt discharge policy, a balancing mechanism has existed in the form of legal provisions which punish abusive individual debtors. The government must also prohibit serial bankruptcy petitions after implementing the debt discharge policy to prevent abuse by dishonest debtors. Thus, it is hoped that the debt discharge policy implementation will be effective, which is only awarded to the honest but unfortunate individual debtors in the economic wheel.

\section{CONCLUSION}

It can be concluded that the Indonesian bankruptcy regime does not adhere to the debt discharge policy for the individual debtors, which caused them compelled to resolve the outstanding debts after bankruptcy. Based on the debtor cooperation theory and the theory of humanitarian debt discharge, the debt discharge policy is rational for implementation in Indonesia. The first and second Sila of Pancasila also support the rationalisation of debt discharge policy in the Indonesian bankruptcy regime. Individual debtors are members of society who must be treated with dignity and humane if they cannot afford to settle their debts. It is also recommended that the Indonesian government learn from Chapter 7 of the United States Bankruptcy Code, the United Kingdom Insolvency Act 1986 and Insolvency Rules 2016, Netherlands Wnsp Procedure, and French Consumer Code on debt discharge policy for the individual debtors. Nevertheless, not every individual debtor should be awarded a debt discharge. Only the honest debtor deserves debt discharge. Debts that arise from criminal activities or involve more significant public interests may not be discharged. Hence, the debt discharge policy should be balanced with punishments for the debtors who attempt to abuse the bankruptcy system. Finally, the forthcoming amendment of Law No. 37 of 2004 on Bankruptcy and Suspension of the Payment must adhere to the debt discharge policy to provide legal certainty on implementing the debt discharge policy for the honest but unfortunate individual debtors.

\section{REFERENCES}

Ali, Muhammad Daud. Hukum Islam: Pengantar Ilmu Hukum Dan Tata Hukum Islam Di Indonesia. Jakarta: Rajawali Pers, 2009.

Anisah, Siti. Perlindungan Kepentingan Kreditor Dan Debitor Dalam Hukum Kepailitan Di Indonesia. Yogyakarta: Total Media, 2008.

—. "Studi Komparasi Terhadap Perlindungan Kepentingan Kreditor Dan Debitor Dalam Hukum Kepailitan.” Jurnal Hukum 16, no. Edisi Khusus (2009): 30-50.

Asyhadie, Zaeni, and Budi Sutrisno. Hukum Perusahaan \& Kepailitan. Jakarta: Erlangga,

${ }^{129}$ McCullough, "Bankruptcy Fraud: Crime without Punishment II.” 
2012.

Atkinson, Abbye. "Consumer Bankruptcy, Nondischargeability, and Penal Debt." Vanderbilt Law Review 70, no. 3 (2017): 917-83.

Azmi, Ruzita, Adilah Abdul Razak, and Siti Nur Samawati Ahmad. "Discharge in Bankruptcy: A Comparative Analysis of Law and Practice Between Malaysia, Singapore and the United Kingdom (UK) - What Can We Learn?" Commonwealth Law Bulletin 43, no. 2 (2017): 203-33.

Backer McKenzie. "Global Restructuring \& Insolvency Guide," 2016. http://restructuring.bakermckenzie.com/wp-content/uploads/sites/23/2016/12/Global-

Restructuring-Insolvency-Guide-New-Logo-France.pdf.

Bos van der Burg Advocaten. "Debt Restructuring for Self-Employed Professionals in the Netherlands." International Network of Law and Consulting Firms, 2019. https://pragma.international/article/debt-restructuring-for-self-employed-professionals-inthe-netherlands.

Clement, Leia A. "A Study on Bankruptcy Crime Prosecution under Title 18: Is the Process Undermining the Goals of the Bankruptcy System." Emory Bankruptcy Developments Journal 31, no. 2 (2015): 409-30.

Efrat, Rafael. "The Evolution of Bankruptcy Stigma." Theoretical Inquiries in Law 7, no. 1 (2006): 364-93.

Elias, Stephen R. The New Bankruptcy: Will It Work for You? 4th ed. California: NOLO, 2011.

Feeney, Joan N., and Theodore W. Connoly. The Road Out of Debt: Bankruptcy and Other Solutions to Your Financial Problems. New Jersey: John Wiley \& Sons, Inc., 2010.

Finnis, John. Natural Law \& Natural Rights. 2nd ed. New York: Oxford University Press, 2011

Flint, Richard E. "Bankruptcy Policy: Toward A Moral Justification for Financial Rehabilitation of the Consumer Debtor." Washington and Lee Law Review 48, no. 2 (1991): 515-77.

Gross, Karen. Failure and Forgiveness: Rebalancing the Bankruptcy System. New Haven: Yale University Press, 1997.

Herdiawanto, Heri, Fokky Fuad Wasitaatmadja, and Jumanta Hamdayama. Spiritualisme Pancasila. Jakarta: Prenada Media, 2018.

Hirsch, Adam J. "Inheritance and Bankruptcy: The Meaning of the 'Fresh Start." Hastings Law Journal 45, no. 2 (1994): 175-248.

Hynes, Richard M. "Why (Consumer) Bankruptcy?" Alabama Law Review 56, no. 1 (2004): 121-79.

Jackson, Thomas H. "The Fresh-Start Policy in Bankruptcy Law." Harvard Law Review 98, no. 7 (1985): 1393-1448.

—. The Logic and Limits of Bankruptcy Law. Washington D.C.: BeardBooks, 2001.

Jacobson, Richard B. "The Structure of Forgiveness." Cardozo Studies in Law and Literature 4, no. 2 (1992): 243-53.

Jordan, Robert L., and William D. Warren. Bankruptcy. 3rd ed. New York: The Foundation 
Press, Inc., 1993.

Kaelan. Etika Kehidupan Berbangsa: Prinsip-Prinsip Etika Dalam Kehidupan Berbangsa Dan Bernegara Berdasarkan Pancasila. Yogyakarta: Paradigma Press, 2018.

—. Negara Kebangsaan Pancasila: Kultural, Historis, Filosofis, Yuridis Dan Aktualisasinya. Yogyakarta: Paradigma Press, 2013.

. The Philosophy of Pancasila: The Way of Life of Indonesian Nation. Yogyakarta: Paradigma Press, 2014.

Kilborn, Jason J. "Foundation of Forgiveness in Islamic Bankruptcy Law: Sources, Methodology, Diversity." American Bankruptcy Law Journal 85 (2011): 323-54.

—. "La Responsabilisation de L'economie: What the United States Can Learn from the New French Law on Consumer Overindebtedness." Michigan Journal of International Law 26, no. 2 (2005): 619-71.

- "Mercy, Rehabilitation, and Quid Pro Quo: A Radical Reassessment of Individual Bankruptcy." Ohio State Law Journal 64, no. 3 (2003): 855-96.

Kilpi, Jukka. The Ethics of Bankruptcy. New York: Routledge, 1998.

King, John. "Moving Beyond the 'Hard'-'Easy' Tug of War: A Historical, Empirical and Theoretical Assessment of Bankruptcy Discharge." Melbourne University Law Review 28, no. 3 (2004): 654-89.

Korobkin, Donald R. "Rehabilitating Values: A Jurisprudence of Bankruptcy." Columbia Law Review 91, no. 4 (1991): 717-89.

Latif, Yudi. Negara Paripurna: Historisitas, Rasionalitas, Dan Aktualitas. 5th ed. Jakarta: Gramedia Pustaka Utama, 2015.

Local Loan Co. v. Hunt (292 U.S. 234) (1934).

Marzuki, Peter Mahmud. Penelitian Hukum. Revised. Jakarta: Prenada Media, 2013.

McCoid, John C. "Discharge: The Most Important Development in Bankruptcy History." American Bankruptcy Law Journal 70, no. 2 (1996): 163-94.

McCullough, Ralph C. "Bankruptcy Fraud: Crime without Punishment II." Commercial Law Journal 102, no. 1 (1997): 1-54.

Milman, David, and Chris Durrant. Corporate Insolvency: Law and Practice. London: Sweet \& Maxwell, 1999.

Morgan Lewis \& Bockius LLP. "Strange Effects of the UK's New Insolvency Law," 2020. https://www.lexology.com/library/detail.aspx?g=29cec1a0-5c67-472f-9b5ebd9866bf7a02.

Netherlands Enterprise Agency. "Debt Restructuring." Business.gov.nl. Accessed November 29, 2020. https://business.gov.nl/regulation/debt-restructuring/.

Ramsay, Iain. “The New Poor Person's Bankruptcy: Comparative Perspectives.” International Insolvency Review 29, no. 1 (2020): 4-24.

Ratnapala, Suri. Jurisprudence. Melbourne: Cambridge University Press, 2009.

Republik Indonesia. Bankruptcy and Suspension of the Payment (2014). Indonesian Civil Code (n.d.). 
Limited Liability Company (2007).

Robert, and Bismar Nasution. "Adoption of Islamic Bankruptcy Law Values into Indonesian Bankruptcy Law to Protect Good Faith Debtors." In 1st International Conference on Law, Governance and Islamic Society (ICOLGIS 2019), 157-61. Banda Aceh: Atlantis Press, 2020.

Shubhan, M.Hadi. Hukum Kepailitan: Prinsip, Norma, Dan Praktik Di Pengadilan. 3rd ed. Jakarta: Prenada Media, 2012.

Shuchman, Philip. "An Attempt at a Philosophy of Bankruptcy." UCLA Law Review 21, no. 2 (1973): 403-76.

Sjahdeini, Sutan Remy. Sejarah, Asas, Dan Teori Hukum Kepailitan: Memahami UndangUndang Nomor 37 Tahun 2004 Tentang Kepailitan Dan Penundaan Kewajiban Pembayaran Utang. 2nd ed. Jakarta: Prenada Media, 2016.

Skeel Jr., David A. "When Should Bankruptcy Be an Option (for People, Places, or Things)?" William \& Mary Law Review 55, no. 6 (2014): 2217-52.

Soeroso, R. Pengantar Ilmu Hukum. Jakarta: Sinar Grafika, 2017.

Sousa, Michael D. "A Delicate Balancing Act: Satisfying the Fourth Amendment While Protecting the Bankruptcy System from Debtor Fraud." Yale Journal on Regulation 28, no. 2 (2011): 367-417.

"The Principle of Consumer Utility: A Contemporary Theory of the Bankruptcy Discharge." Kansas Law Review 58, no. 3 (2010): 553-614.

Spooner, Joseph. "Explaining Personal Insolvency and the Law," 2020. https://www.law.ox.ac.uk/housing-after-grenfell/blog/2020/07/explaining-personalinsolvency-and-law.

Stowell, Nicole Forbes, and Katherine Barker. "Fraud, Fraud, Fraud: Mortgage Fraud and Bankruptcy Fraud." Real Estate Review 40, no. 2 (2011): 47-62.

Tabb, Charles Jordan. "The Historical Evolution of the Bankruptcy Discharge." American Bankruptcy Law Journal 65, no. 1 (1991): 325-71.

. "The History of the Bankruptcy Laws in the United States." American Bankruptcy Institute Law Review 3 (1995): 5-51.

- "The Scope of the Fresh Start in Bankruptcy: Collateral Conversions and the Dischargeability Debate." The George Washington Law Review 59, no. 1 (1990): 56-113.

Toha, Kurnia, and Sonyendah Retnaningsih. "Legal Policy Granting Status of Fresh Start to the Individual Bankrupt Debtor in Developing the Bankruptcy Law in Indonesia." Academic Journal of Interdisciplinary Studies 9, no. 2 (2020): 157-61.

Trumbull, Gunnar. "Consumer Protection in French and British Credit Markets," 2008. https://www.jchs.harvard.edu/sites/default/files/media/imp/ucc08-17_trumbull.pdf.

United States Courts. "Chapter 7 - Bankruptcy Basics," 2020. https://www.uscourts.gov/services-forms/bankruptcy/bankruptcy-basics/chapter-7bankruptcy-basics.

Widjaja, Gunawan. Seri Hukum Bisnis: Daluwarsa. Jakarta: RajaGrafindo Persada, 2005.

Wignjosoebroto, Soetandyo. Pedoman \& Tata Cara Penulisan Disertasi. Malang: Madani, 
2017.

Yaqin, Anwarul. Legal Research and Writing. Petaling Jaya: Dophin Press, Sdn. Bhd., 2007.

Zeigler, Luther. "The Fraud Exception to Discharge in Bankruptcy: A Reappraisal." Stanford Law Review 38, no. 3 (1986): 891-918.

Zweigert, Konrad, and Hein Kotz. An Introduction to Comparative Law. Third. New York: Oxford University Press, 1998.

Zywicki, Todd J. "Bankruptcy Law as Social Legislation." Texas Review of Law \& Politics 5, no. 2 (2001): 1-32. 